\title{
Ascorbic Acid 2- $O-\alpha$-Glucoside-Induced Redox Modulation in Human Keratinocyte Cell Line, SCC: Mechanisms of Photoprotective Effect against Ultraviolet Light $B$
}

\author{
Eriko Mryai, ${ }^{a, b}$ Mitsuhiro Yanagida,,${ }^{a, b}$ Jun-ichi Akryama, ${ }^{b}$ and Itaru Yamamoto ${ }^{*, a}$ \\ Department of Immunochemistry, Faculty of Pharmaceutical Sciences, Okayama University, ${ }^{a} 1-1-1$ Tsushima-naka, \\ Okayama 700, Japan and Department of Research and Development, Kaminomoto Co., Ltd., ${ }^{b}$ 3-3-25 Kumochibashi- \\ dori, Chuo-ku, Kobe 651, Japan. Received September 27, 1996; accepted February 27, 1997
}

\begin{abstract}
We previously reported that the topical application of ascorbic acid $2-O$ - $\alpha$-glucoside (AA-2G) suppressed the cutaneous inflammation by ultraviolet irradiation in human and guinea pigs (Miyai et al., Nishinihon J. Dermatol., $58,439-443$ (1996)). In this paper, the effect of AA-2G on the lethal damage induced by ultraviolet B (UVB) was studied using a human keratinocyte cell line, SCC, established from squamous cell carcinoma. The photoprotective effect of AA-2G on cytotoxicity of UVB in SCC cells was dose dependent $(0.125-1 \mathrm{mM})$ and more effective than that of ascorbic acid (AsA) at $1 \mathrm{mM}$. This protection was completely abolished in the presence of an $\alpha$-glucosidase inhibitor, castanospermine, indicating that release of AsA from this derivative was essential for reduction of the actinic injury. AA-2G significantly suppressed cytotoxicities of hydrogen peroxide and superoxide anion produced by xanthine and xanthine oxidase. AA-2G exhibited a preventive effect against the cytotoxicity produced by tert-butylhydroperoxide, an inducer of lipid peroxidation, in the presence of $\alpha$-tocopherol, but not in the absence of $\alpha$-tocopherol. Cytotoxicity of UVB was also effectively reduced by the combination of AA-2G and $\alpha$-tocopherol. In addition, AA-2G reduced UVB-promoted formation of lipid peroxide and accumulation of lipofuscin, which is known to be a complex of cellular proteins and metabolites of lipid peroxide.

These data suggest that AA-2G prevents the acute inflammation induced by UVB irradiation partly through scavenging reactive oxygen species and potentiating the antioxidative activity of $\alpha$-tocopherol.
\end{abstract}

Key words ascorbic acid 2-O- $\alpha$-glucoside; ascorbic acid; ultraviolet $\mathrm{B}$; redox modulation; photoprotective effect

Ultraviolet (UV) rays are potent agents which induce functional harm to and cause the death of epidermal cells, which are believed to reflect cutaneous damage. ${ }^{1,2)}$ Martin and Cotter $^{3)}$ reported that the short period of UVB irradiation induced massive and rapid programmed cell death of the human leukaemia HL-60 cell line and a variety of other human cell lines. More prolonged irradiation of these cells at the same level of exposure resulted in an accelerated form of cell death which they tentatively suggested to be necrosis. It has been proven that the lethal damage by UVB is partly mediated by reactive oxygen species (ROS)-caused oxidative injury ${ }^{3)}$ and assumed that the balance of the oxidative stress and intracellular antioxidative activity might determine the fate of irradiated cells, death or survival. ${ }^{4)}$ Some antioxidants and inducers of anti-oxidative endogenous proteins have therefore been evaluated for their photoprotective ability in vivo ${ }^{5,6)}$ and in vitro. ${ }^{7)}$

Ascorbic acid (AsA) functions not only as a biological co-factor but also as an available barrier against oxidative damage due to its reducing properties. Darr et al ${ }^{8)}$ reported that daily pretreatment with AsA from $3 \mathrm{~d}$ to 1 week served to protect skin from UVB-induced inflammation. However, chemical modification to improve the stability of AsA is essential from a practical standpoint. Yamamoto et al. recently developed a new stable form of AsA, ascorbic acid 2- $O-\alpha$-glucoside (AA-2G),${ }^{9-11)}$ and demonstrated that AA-2G exhibits physiological effects of AsA, such as antiscorbutic activity in guinea pigs ${ }^{12)}$ and stimulation of collagen synthesis in cultured human skin fibroblasts. ${ }^{13)}$ Subsequent experiments demonstrated that AA$2 \mathrm{G}$ is processed by $\alpha$-glucosidase to release active AsA in vivo and in vitro. We showed that $\mathrm{AA}-2 \mathrm{G}$ was the most

* To whom correspondence should be addressed. effective compound among several AsA derivatives in preventing UV-caused erythema in human and guinea pig skin. ${ }^{14)}$ It is difficult, however, to elucidate the photoprotective mechanism of AA-2G in an in vivo experiment.

In this study, we investigated the effect of $A A-2 G$ on lethal damage by UVB from the viewpoint of intracellular redox modulation as effective ascorbate. As a result, it is suggested that the prevention of epidermal cell injury by AA-2G was accomplished by the AsA-induced positive regulation of cellular antioxidative ability.

\section{MATERIALS AND METHODS}

Materials and Cells The material sources used in this work were as follows: AA-2G from Hayashibara Biochemical Labs. (Okayama, Japan); sodium ascorbate, hydrogen peroxide, xanthine, 1,3-dimethyl 2-thiourea (DMTU), DL- $\alpha$-tocopherol, tert-butylhydroperoxide (BHP), and butylated hydroxytoluene (BHT) from Wako Pure Chemical Industries, Ltd. (Osaka, Japan); castanospermine (CSP) from Funakoshi Co., Ltd. (Tokyo, Japan); neutral red assay kit from Kurabo Co., Ltd. (Osaka); Dulbecco's minimum essential medium (DMEM) and L-glutamine from Nissui Pharmaceutical Co. (Tokyo); fetal bovine serum (FBS) from International Reagents Co. (Kobe, Japan); and catalase (bovine liver, $11000 \mathrm{U} / \mathrm{mg}$ ), glutathione, reduced form (GSH), superoxide dismutase (SOD) and thiobarbituric acid (TBA) from Sigma Co., Ltd. (St. Louis, MO, U.S.A.). Other reagents used were of analytical grade.

SCC cells were kindly provided by the Department of Dermatology, Shinshu University School of Medicine and maintained in DMEM supplemented with $4.0 \mathrm{~mm}$

(C) 1997 Pharmaceutical Society of Japan 
L-glutamine and $10 \%$ inactivated $\mathrm{FBS}$ at $37^{\circ} \mathrm{C}$ under $5 \%$ $\mathrm{CO}_{2}$ atmosphere.

Cytotoxicity Test of UVB The maximum protective activity of AA-2G against UVB cytotoxicity needs pre $(9 \mathrm{~h})$ - and post $(24 \mathrm{~h})$-cultivation with AA-2G, as reported previously. ${ }^{15)} \mathrm{SCC}$ cells $\left(2.5 \times 10^{4} /\right.$ well $)$ were cultured in 24-well dishes (Falcon) for $3 \mathrm{~d}$ and preincubated with various concentrations of test compounds for $9 \mathrm{~h}$. The adhering cells were washed twice with phospate buffered saline (PBS) and irradiated for $80 \mathrm{~s}$ by UVB $\left(20 \mathrm{~mJ} / \mathrm{cm}^{2}\right)$ with an array of four fluorescent tubes (FL20S-E, Toshiba Electric Co., Ltd., Tokyo) through PBS $(500 \mu \mathrm{l} /$ well). The intensity of UVB was fixed at $0.25 \mathrm{~mW} / \mathrm{cm}^{2}$ by measurement with a UV radiometer (model UVR-305/365.D(II), Tokyo Kagaku Kiki Co., Ltd., Tokyo) in each experiment. Immediately after irradiation, cells were recultured for $24 \mathrm{~h}$ in the media containing test compounds. The assay for uptake of neutral red into viable cells was used to estimate cytotoxicity as described previously. ${ }^{15)}$ In this method, the viability of control cultures decreased to $25-50 \% 24 \mathrm{~h}$ after irradiation.

Cytotoxicity Test of Reactive Oxygens and BHP The time schedule differed from the Cytotoxicity Test of UVB as follows: the preincubation time with test compounds was $7 \mathrm{~h}$ and the exposure period with hydrogen peroxide $(0.4 \mathrm{~mm})$, xanthine $(1 \mathrm{~mm})+$ xanthine oxidase $(20 \mathrm{mU} / \mathrm{ml})$ or BHP (2 mM) was $2 \mathrm{~h}$. Other experimental conditions were identical to those of the above section.

Detection of Lipofuscin The fluorescent pigment, lipofuscin, accumulated in UVB-irradiated cells was detected by the method described by Itoh et al. ${ }^{16)}$ with slight modifications. Briefly, SCC cells grown for $4 \mathrm{~d}$ in $35 \mathrm{~mm}$ dishes $\left(4 \times 10^{4}\right.$ cells $/$ dish at plating $)$ were irradiated by UVB at $0.867 \mathrm{~mW} / \mathrm{cm}^{2}$ for 30 min or exposed to BHP $(2 \mathrm{~mm})$ for $3 \mathrm{~h}$. The cells were harvested using a rubber policeman, and suspended in $200 \mu \mathrm{l}$ of $1.15 \% \mathrm{KCl}$. Protein concentration of the cell suspension was measured by the modified Bradford's method. ${ }^{17)}$ An aliquot of suspension $(0.5 \mathrm{mg}$ protein) was washed 3 times with a mixture of ethanol and ether $(3: 1)$ and dissolved in $0.5 \mathrm{ml}$ of $15 \%$ sodium lauryl sulfate in PBS at $37^{\circ} \mathrm{C}$. After centrifugation at $3000 \mathrm{rpm}$ for $5 \mathrm{~min}$, the fluorescence of the supernatant was measured with a spectrofluorophotometer (model RF-540, Shimadzu, Tokyo) keeping the excitation wavelength at $355 \mathrm{~nm}$ and the emission wavelengths at $380-520 \mathrm{~nm}$.

Assay of Lipid Peroxidation The amount of lipid peroxide was measured by estimating malondialdehyde using the TBA test. ${ }^{18)}$ Reaction mixtures were composed of $200 \mu \mathrm{l}$ cell suspension and $400 \mu \mathrm{l}$ of TBA reagent ( $200 \mu \mathrm{l}$ of $30 \%$ trichloroacetic acid (TCA), $100 \mu \mathrm{l}$ of $1 \mathrm{~N}$ $\mathrm{HCl}, 92 \mu \mathrm{l}$ of $\mathrm{H}_{2} \mathrm{O}, 1.504 \mathrm{mg}$ TBA and $8 \mu \mathrm{l}$ of BHT) and were incubated at $95^{\circ} \mathrm{C}$ for $30 \mathrm{~min}$. After cooling in a water bath, $600 \mu \mathrm{l}$ of $n$-butanol was added to these mixtures, followed by centrifugation at $2000 \mathrm{rpm}$ for $10 \mathrm{~min}$. Absorbance of the supernatants at $540 \mathrm{~nm}$ was measured by a spectrophotometer (model 124-1618, Hitachi, Tokyo).

Statistical Analysis Means and standard deviations were compared by Student's $t$-test with significant probability levels of $<0.05$.

\section{RESULTS}

Photoprotective Effects of AA-2G on UVB-Induced Cytotoxicity in SCC Cells AA-2G prevented a decrease in viable cell number by UVB exposure in a dose-dependent manner from 0.125 to $1 \mathrm{~mm}$, but the photoprotection of AsA reached a plateau at $0.25 \mathrm{~mm}$ (Fig.1). The protective ability of AA-2G against UVB toxicity was completely abolished in the presence of $1 \mu \mathrm{M}$ CSP, an inhibitor of $\alpha$-glucosidase (Table 1), suggesting that AsA was an active form of AA-2G. Figure 2 illustrates effects of various antioxidants, such as SOD, catalase, GSH, DMTU, BHT and $\alpha$-tocopherol, on UVB-induced cytotoxicity. Each compound was added to the culture medium at its optical concentration. All drugs tested in this experiment showed a significant preventive effect on the actinic cytotoxicity, but their efficacies were inferior or equivalent to AA-2G (Fig. 2). These findings indicate that the scavenging of generated ROS by AsA is probably related to the photoprotection of $\mathrm{AA}-2 \mathrm{G}$.

Effect of AA-2G on Oxidative Stress in SCC Cells We

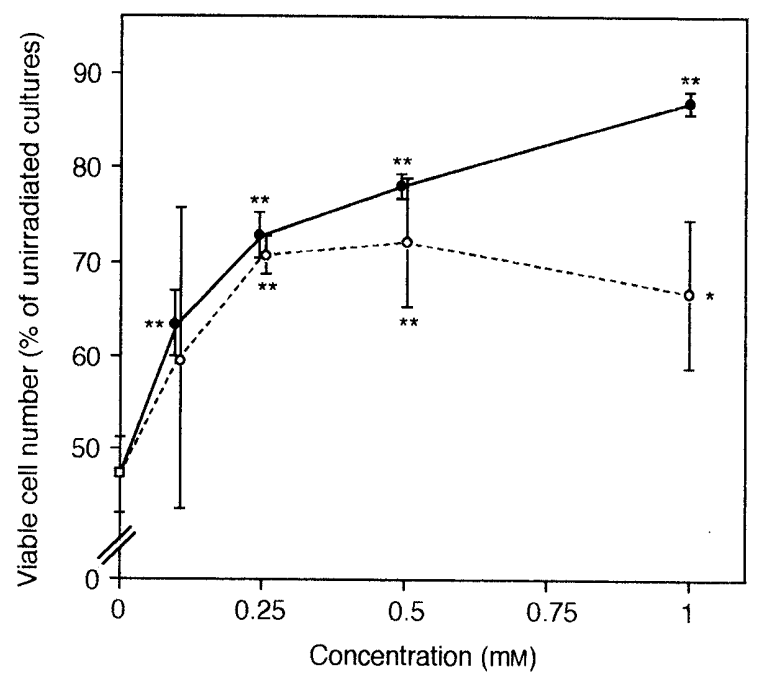

Fig. 1. Comparison of AA-2G with Sodium Ascorbate on the Protective Effect against UVB-Induced Cytotoxicity

SCC cells pretreated for $9 \mathrm{~h}$ with various concentrations of AA-2G $(9)$ or AsA (O) were exposed to UVB $\left(20 \mathrm{~mJ} / \mathrm{cm}^{2}\right)$ and recultured. After $24 \mathrm{~h}$, the number of viable cells was measured by NR assay. Data are expressed as means \pm S.D. of quadruplicate cultures. $* p<0.05, * * p<0.01$ compared with UVB-irradiated control cultures.

Table 1. Abolishment of AA-2G-Induced Protection against Cytotoxicity of UVB by $\alpha$-Glucosidase Inhibitor, CSP

\begin{tabular}{|c|c|c|c|c|}
\hline $\begin{array}{c}\text { Irradiation } \\
\text { of UVB }\end{array}$ & $\begin{array}{c}\text { AA-2G } \\
(1 \mathrm{~mm})\end{array}$ & $\begin{array}{c}\text { CSP } \\
(10 \mu \mathrm{M})\end{array}$ & $\begin{array}{c}\text { Viable cell number } \\
\times 10^{4} \text { cells } / \text { well }\end{array}$ & $\begin{array}{l}\% \text { of } \\
\text { Unirradiated } \\
\text { cultures }\end{array}$ \\
\hline Unirradiated cells & - & - & $8.70 \pm 0.08$ & 100 \\
\hline \multirow[t]{4}{*}{ Irradiated cells } & - & - & $4.22 \pm 0.44$ & 48.5 \\
\hline & + & - & $5.84 \pm 0.16]^{*}$ & 67.1 \\
\hline & - & + & $4.64 \pm 0.18$ & 53.3 \\
\hline & + & + & $4.76 \pm 0.21$ N.S. & 54.0 \\
\hline
\end{tabular}

SCC cells pretreated for $9 \mathrm{~h}$ with or without AA-2G (1.0 mM) were exposed to UVB $\left(20 \mathrm{~mJ} / \mathrm{cm}^{2}\right)$ and recultured. After $24 \mathrm{~h}$, the number of viable cells was measured by NR assay. Data are expressed as means \pm S.D. of quadruplicate cultures. $* p<0.01$, N.S.: not significant. 


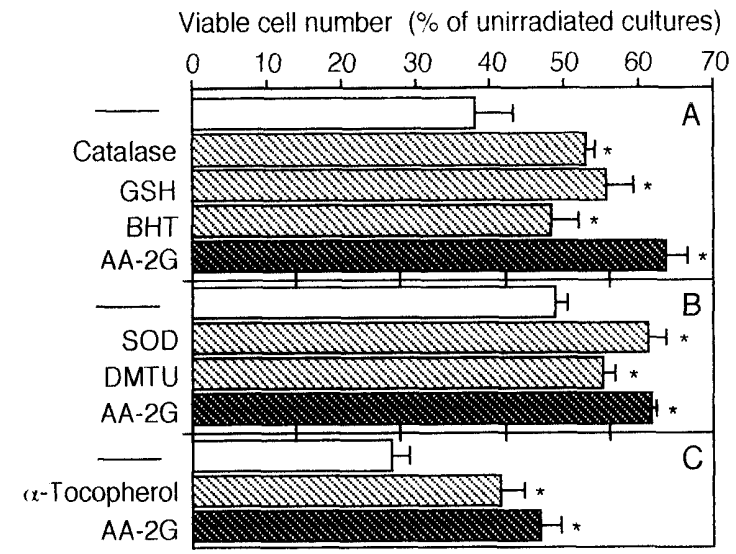

Fig. 2. Reduction of Cytotoxicity of UVB by Various Antioxidants SCC cells pretreated for $9 \mathrm{~h}$ with catalase $(100 \mathrm{U} / \mathrm{ml})$, GSH ( $1 \mathrm{~mm}), \mathrm{BHT}(0.1 \mathrm{~mm})$, SOD $(500 \mathrm{U} / \mathrm{ml})$, DMTU $(0.1 \mathrm{mM}), \alpha$-tocopherol $(2.5 \mathrm{mM})$ or AA-2G $(1 \mathrm{mM})$ were exposed to UVB $\left(20 \mathrm{~mJ} / \mathrm{cm}^{2}\right)$ and recultured. After $24 \mathrm{~h}$, the number of viable cells was measured by NR assay. Data are expressed as means + S.D. of quadruplicate cultures. $* p<0.01$ compared with UVB-irradiated control cultures.
Table 2. Effective Reduction of UVB-Induced Cytotoxicity by the Combination of AA-2G and $\alpha$-Tocopherol

\begin{tabular}{|c|c|c|c|c|}
\hline \multirow{2}{*}{$\begin{array}{l}\text { Irradiation } \\
\text { of UVB }\end{array}$} & \multirow{2}{*}{$\begin{array}{l}\alpha \text {-Tocopherol } \\
(\mathrm{mm})\end{array}$} & \multicolumn{3}{|c|}{$\begin{array}{l}\text { Viable cell number } \\
\left(\times 10^{4} \text { cells } / \text { well }\right)\end{array}$} \\
\hline & & $\begin{array}{l}\text { Without } \\
\text { AA-2G }\end{array}$ & & $\begin{array}{l}\text { With AA-2G } \\
\quad(1 \mathrm{~mm})\end{array}$ \\
\hline Unirradiated cells & 0 & $8.39 \pm 0.90$ & \multirow{5}{*}{ ** } & N.D. \\
\hline \multirow[t]{4}{*}{ Irradiated cells } & 0 & $2.23+0.21$ & & $3.93 \pm 0.23$ \\
\hline & 0.1 & $2.26 \pm 0.02$ & & $4.10 \pm 0.17 *$ \\
\hline & 1.0 & $2.51 \pm 0.27$ & & $5.10 \pm 0.53]$ \\
\hline & 2.5 & $3.47 \pm 0.37$ & & $6.12 \pm 0.31$ \\
\hline
\end{tabular}

SCC cells were precultivated for $9 \mathrm{~h}$ with $x$-tocopherol $(0.1-2.5 \mathrm{~mm})$ in the presence or absence of AA-2G $(1 \mathrm{~mm})$ and exposed to UVB $\left(20 \mathrm{~mJ} / \mathrm{cm}^{2}\right)$. After $24 \mathrm{~h}$, the number of viable cells was measured by NR assay. Datit are expressed as means \pm S.D. of quadruplicate cultures. $* p<0.05, * * p<0.01$. N.D.: not done.
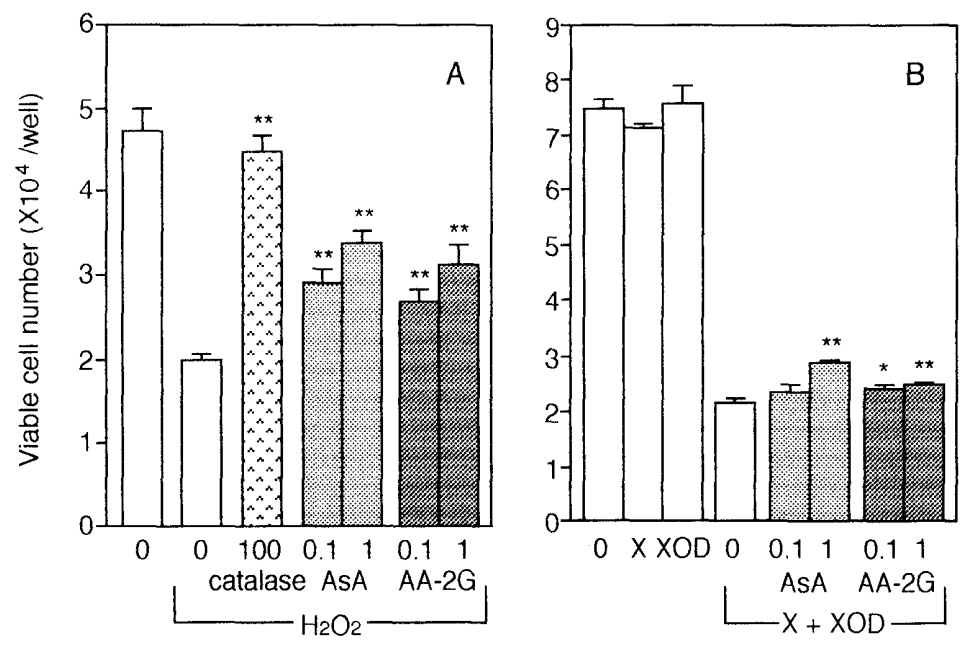

Fig. 3. Inhibitory Effect of $\mathrm{AA}-2 \mathrm{G}$ on the Cytotoxicity of Reactive Oxygens

SCC cells pretreated for $7 \mathrm{~h}$ with $\mathrm{AA}-2 \mathrm{G}$, AsA $(0.1$ or $1 \mathrm{~mm})$ or catalase $(100 \mathrm{U} / \mathrm{ml})$ were exposed to $\mathrm{A}$; hydrogen peroxide $\left(\mathrm{H}_{2} \mathrm{O}_{2}, 0.4 \mathrm{~mm}\right)$ or $\mathrm{B} ; \mathrm{xanthine}(\mathrm{X}, 1 \mathrm{~mm})$ and xanthine oxidase (XOD, $20 \mathrm{mU} / \mathrm{ml}$ ). After $2 \mathrm{~h}$, the number of viable cells was measured by NR assay. Data are expressed as means \pm S.D. of triplicate cultures. $* p<0.05, * * p<0.01$ compared with control cultures exposed to each reactive oxygen.

next determined the protective capacity of AA-2G against oxidative stress triggered by ROS and a potent inducer of lipid peroxidation, BHP. Exposure to $0.4 \mathrm{~mm}$ hydrogen peroxide for $2 \mathrm{~h}$ reduced the number of viable cells by $57.9 \%$, which was diminished to $34.2 \%$ and $28.3 \%$ by $1 \mathrm{~mm}$ AA-2G and AsA, respectively (Fig. 3A). In the case of superoxide anion produced by $1 \mathrm{~mm}$ xanthine and $20 \mathrm{mU} / \mathrm{ml}$ xanthine oxidase, the protective abilities were slight (Fig. 3B). BHP-induced cytotoxicity was significantly prevented by $\alpha$-tocopherol (a lipophilic free radical scavenger), but not by either AA-2G nor AsA (Fig. 4). On the other hand, AA-2G significantly increased the preventive effect of $\alpha$-tocopherol by $72 \%$ (Fig. 4), indicating that AsA reduced the rate of oxidative consumption of $\alpha$-tocopherol. In fact, the combined addition of AA-2G and $\alpha$-tocopherol was effective in preventing UVB cytotoxicity (Table 2). These results suggested that both scavenging ROS and regenerating oxidized $\alpha$-tocopherol were involved in the reduction of actinic injury with AA-2G.
Inhibition of UVB-Induced Oxidative Damage by AA2G Lipofuscin is termed an age pigment with fluorescence in vivo, and has been defined as one of the final metabolites of lipid peroxide. ${ }^{19)}$ We observed that UVB irradiation caused the accumulation of lipofuscin in SCC cells, which was believed to indicate oxidative damage (data not shown). Seven-hour preincubation with AA-2G dramatically prevented the intracellular formation of lipofuscin by UVB (Fig. 5A) and the efficiency of AA$2 \mathrm{G}$ was abolished by CSP (Fig. 5B). Under the same conditions, $1 \mathrm{~mm}$ of AA-2G reduced lipid peroxidation by $74.0 \%$, whose potency was higher than $2.5 \mathrm{~mm}$ of $\alpha$-tocopherol (Table 3).

\section{DISCUSSION}

We showed here that AA-2G, a stable form of AsA, prevented oxidative injury by UVB in cultured epidermal cells (Fig. 1). It is likely that AsA released from AA-2G through enzymatic hydrolysis by $\alpha$-glucosidase is 


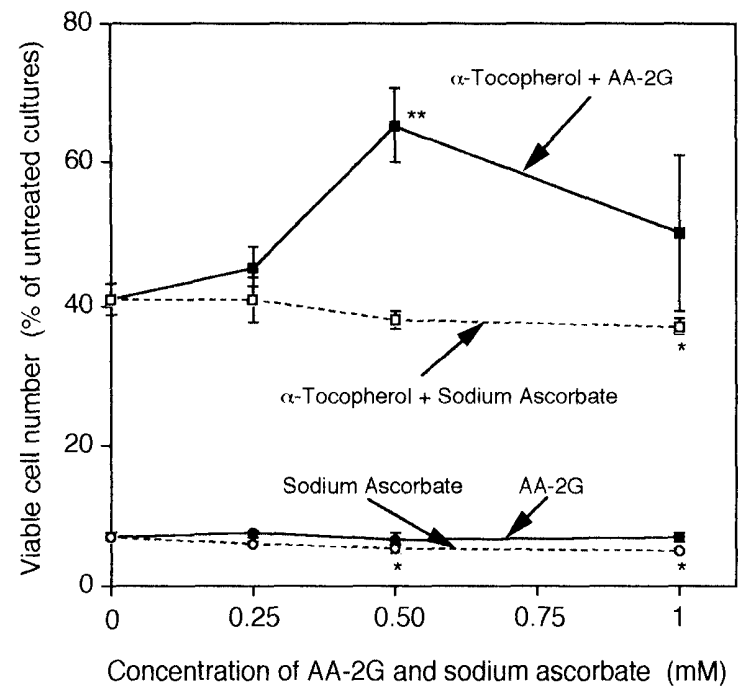

Fig. 4. Enhancement of Preventive Effect of $\alpha$-Tocopherol on BHPInduced Cytotoxicity in SCC Cells by AA-2G

SCC cells were preincubated with $\mathrm{AA}-2 \mathrm{G}$ or sodium ascorbate in the presence or absence of $x$-tocopherol $(2.5 \mathrm{~mm})$ for $7 \mathrm{~h}$, and exposed to BHP (2 mM). After $2 \mathrm{~h}$, the number of viable cells was measured by NR assay. Data are expressed as means \pm S.D. of triplicate cultures. $* p<0.05, * * p<0.01$ compared with the corresponding cultures with or without $\alpha$-tocopherol.
A

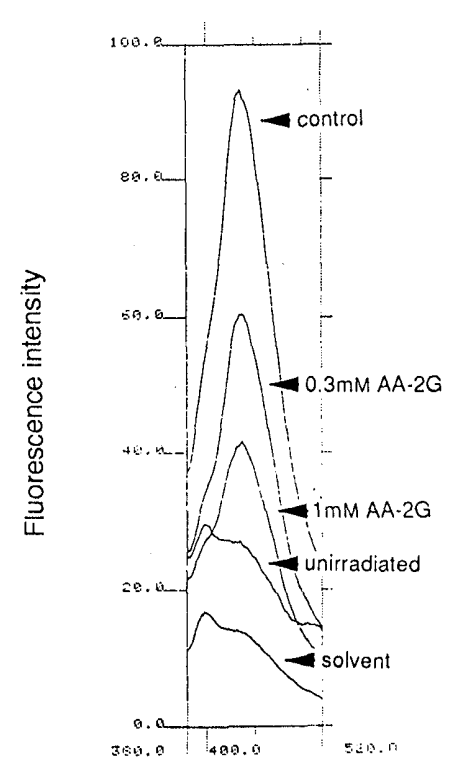

B

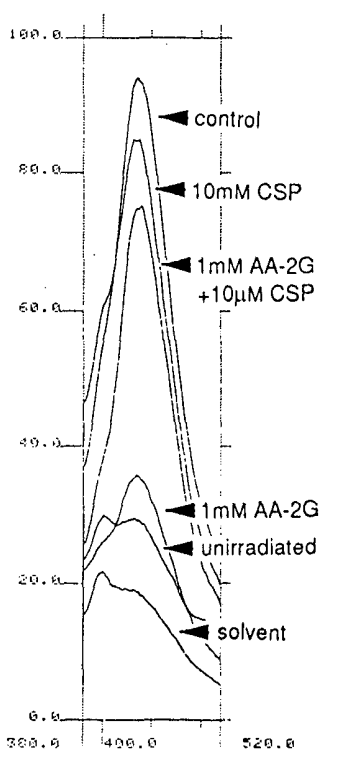

Emission wavelength $(\mathrm{nm})$

Fig. 5. Inhibition of Synthesis of Lipofuscin in UVB-Irradiated SCC Cells by AA-2G

(A) SCC cells, precultivated with or without AA-2G $(0.3,1 \mathrm{~mm})$, were exposed to UVB $\left(1.5 \mathrm{~J} / \mathrm{cm}^{2}\right)$ and immediately harvested. The protein content of harvested cells was measured and cell suspension $(0.5 \mathrm{mg}$ protein) was assayed for lipofuscin by the method described in Materials and Methods. (B) SCC cells, precultivated with AA-2G $(1 \mathrm{mM})$ in the presence or absence of CSP $(10 \mu \mathrm{M})$, were exposed to UVB $\left(1.5 \mathrm{~J} / \mathrm{cm}^{2}\right)$

involved in the suppressive effect of AA-2G on UVBinduced cytotoxicity, because the photoprotective effect of AA-2G was abrogated by an $\alpha$-glucosidase inhibitor, CSP (Table 1) and AsA itself reduced the cytotoxicity of UVB (Fig. 1). Consistent with these observations, AA-2G exhibits the physiological effect of AsA, such as antiscorbutic activity in guinea pigs and stimulation of collagen synthesis in cultured human skin fibroblasts. ${ }^{2,13)}$
Table 3. Inhibition of UVB-Induced Lipid Peroxidation of SCC Cells by AA-2G

\begin{tabular}{lcc} 
Test compound & $\begin{array}{c}\text { UVB-induced lipid peroxidation } \\
\text { (nmol MDA/mg protein) }\end{array}$ & $\begin{array}{c}\text { Inhibition } \\
(\%)\end{array}$ \\
\hline- & $0.269 \pm 0.057$ & - \\
AA-2G & $0.070 \pm 0.014^{* *}$ & 74.0 \\
$\alpha$-Tocopherol & $0.109 \pm 0.007^{*}$ & 59.5
\end{tabular}

SCC cells, precultivated with AA-2G (1 mm) or $x$-tocopherol $(2.5 \mathrm{~mm})$ for $9 \mathrm{~h}$, were exposed to UVB $\left(1.5 \mathrm{~J} / \mathrm{cm}^{2}\right)$ and immediately harvested. The protein concentration was measured by modified Bradford's method. Lipid peroxide was assayed by estimating malondialdehyde (MDA) using the TBA test. Data are expressed as means \pm S.D. of triplicate cultures. $* p<0.05, * * p<0.01$ compared with control cultures.

We should mention that the protective ability of AA-2G against UVB injury was superior to that of AsA (Fig. 1). Such a difference has been thought to depend on the individial prooxidant activity and the uptake of AsA into cells. AsA exhibited a cytotoxic effect via the production of superoxide anion, ${ }^{20,21)}$ hydrogen peroxide $\left(\mathrm{H}_{2} \mathrm{O}_{2}\right)^{22-24)}$ and hydroxy radical $(\cdot \mathrm{OH})^{25)}$ on normal and tumor cells in vitro. We previously reported that an abnormally accumulated AsA in human and chick embryo fibroblasts cultured at low density led to cell death, whereas AA-2G did not show such cytotoxicity. ${ }^{25)}$ AsA-treated fibroblasts incorporates a twelve-fold amount of AsA compared with AA-2G-treated cells. ${ }^{25)}$ This evidence indicates that AsA generates ROS by itself, which must be amplified by the striking elevation of AsA in the cells. AA-2G is hardly autooxidized (not being a trigger to produce ROS) but continuously releases a small amount of AsA into cells to express its full physiological activities. $^{9-11)}$ That is responsible for the efficiency of AA-2G in the photoprotection as described here.

One underlying mechanism of the initiation of UVinduced erythema may be the photochemical production of reactive intermediates ${ }^{26)}$ which cause a propagation of lipid peroxidation by radical reactions. ${ }^{27)}$ In the current experiment, several radical scavengers like AsA, catalase, GSH, SOD, DMTU and $\alpha$-tocopherol showed a protective effect against UVB cytotoxicity (Fig. 2). It follows from this that these oxidative processes are involved in actinic cellular degeneration.

Among ROS, hydroxy radical generated from $\mathrm{H}_{2} \mathrm{O}_{2}$ in the presence of $\mathrm{Fe}^{2+}$ ion ${ }^{28)}$ has the highest reactivity with chromosomal DNA, leading to cell death. AsA is a free radical scavenger with a broad capacity, and it is reported to react most rapidly with $\cdot \mathrm{OH}^{29}{ }^{29}$ As shown in Fig. 3, AA-2G and AsA reduced more efficiently the cytotoxicity of $\mathrm{H}_{2} \mathrm{O}_{2}$ than that of superoxide anion produced by xanthine plus xanthine oxidase. On the other hand, neither suppressed the cytotoxicity of BHP by triggering lipid peroxidation (Fig. 4), suggesting their lack of ability in reducing lipid radicals and peroxide. From this view point one may say that AA-2G prevents such oxidative damages of UVB mainly by scavenging $\mathrm{H}_{2} \mathrm{O}_{2}$ and possibly $\cdot \mathrm{OH}$.

With regard to the cytotoxicity of BHP, AA-2G, which by itself had no effect, exhibited a preventive effect in the presence of $\alpha$-tocopherol (Fig. 4). Therefore, AA-2G enhances the protective activity of $\alpha$-tocopherol against 
the peroxidation. The measurement of lipid peroxide (Table 2) and lipofuscin (Fig. 5) proved that AA-2G effectively reduced the oxidative stress on UVB-irradiated cells. It seems reasonable to conclude that AsA released from AA-2G reinforces the cellular defensive activity against the oxidative stress of UVB by dual actions. One is the scavenging of ROS and the other is the regeneration of $\alpha$-tocopherol from $\alpha$-tocopheroxyl radical, which enhances the chain-breaking activity on lipid peroxidation.

A synergistic antioxidative effect with AsA and $\alpha$ tocopherol in phospholipid liposome ${ }^{30)}$ and low density lipoprotein has been reported, ${ }^{31)}$ but we did not observe this in the cytotoxic experiment of BHP unless AA-2G was tested. AsA itself showed lethal damage in the presence of BHP (Fig. 4). Added to this, AsA, but not AA-2G, promoted the BHP-induced production of lipid peroxide (unpublished data). AsA is easily autooxidated to radical form of monodehydroascorbic acid in the presence of metal ions $\left(\mathrm{Fe}^{2+}\right.$ or $\left.\mathrm{Cu}^{2+}\right)$. Such an autooxidative reaction of AsA causes a degradation and/or polymerization of biopolymers by ROS generated as an active intermediate. $^{20-25)}$ Though the exact mechanism of AsA-induced toxicity remains unknown, we have speculated that ROS accumulates during its autooxidation or its direct interaction with BHP.

AA-2G-induced modulation of redox status is likely to be involved in the photoprotective effect. There are many reports demonstrating that the epidermal cells possess the mechanism to maintain the intracellular redox status. $^{32-34)}$ The change of redox potential leads to oxidative stress, resulting in functional harm and death of cells. ${ }^{5)}$ Studying the defense mechanism of skin provides evidence that oxidative processes develop in UV-caused acute inflammation. ${ }^{35)}$ Shindo et al. ${ }^{36)}$ demonstrated that UV induced a decrease in enzymatic and non-enzymatic antioxidative activities in epidermis and dermis in hairless mice. The point is that the balance of oxidative damage caused by ROS and free radicals and the cellular antioxidative activity should be maintained at a normal level. The unbalanced condition leads to oxidative stress in cutaneous cells and finally the acute inflammation occurs. The present study suggests that AA-2G and AsA induce a resistance to the UVB-triggered oxidative damage in cultured cells. We previously reported that the topical application of AA-2G prevented UV-provoked inflammation and pigmentation in human skin. ${ }^{14)}$ It seems reasonable to suppose that AA-2G supplies AsA to cells and regulates the redox status to raise the defensive activity against oxidative stresses like UV. This stable derivative is believed to be available as an AsA source in photoprotective research and skin biology.

\section{REFERENCES}

1) Tyrrell R. M., Pidoux M., Cancer Res., 47, 1825-1829 (1987).
2) Martin S. J., Cotter T. G., Int. J. Radiat. Biol., 59, 1001-1016 (1991).

3) Fuchs J., Packer L. (ed.), "Oxidative Stress in Dermatology," Marcel Dekker, Inc., New York, 1993, pp. 29-47.

4) Sato N., Iwata S., Nakamura K., Hori T., Mori K., Yodoi J., $J$. Immunol., 154, 3194-3203 (1995).

5) Danno K., Horio T., Takigawa M., Imamura S., J. Invest. Dermatol., 83, 166-168 (1984).

6) Hanada K., Gange R. W., Connor M. J., J. Invest. Dermatol., 96, 838-840 (1991).

7) Chan J. T., Black H. S., J. Invest. Dermatol., 68, 366-368 (1977).

8) Darr D., Combs S., Dunston S., Manning T., Pinnel S., Br. J. Dermatol., 127, 247--253 (1992).

9) Yamamoto I., Muto N., Nagata E., Nakamura T., Suzuki Y., Biochim. Biophys. Acta, 1035, $44-50$ (1990).

10) Muto N., Nakamura T., Yamamoto I., J. Biochem. (Tokyo), 107, $222-227(1990)$.

11) Yamamoto I., Muto N., Murakami K., Suga S., Yamaguchi H., Chem. Pharm. Bull., 38, 3020-3023 (1990).

12) Yamamoto I., Suga S., Mitoh Y., Tamaka M., Muto N., J. Pharmacobio-Dyn., 13, 688-695 (1990).

13) Yamamoto I., Muto N., Murakami K., Akiyama J., J. Nutr., 122, $871-877(1992)$.

14) Miyai E., Yamamoto I., Akiyama J., Yanagida M., Nishinihon J. Dermatol., 58, 439 - 443 (1996).

15) Miyai E., Yanagida M., Akiyama J., Yamamoto I., Biol. Pharm. Bull., 19, $984-987$ (1996).

16) Itoh F., Horie T., Awazu S., Arch. Biochem. Biophys., 264, 184-191 (1988).

17) Read S. M., Northcote D. H., Anal. Biochem., 116, 53-64(1981).

18) Esterbauer H., Cheeseman K. H., Methods Enzymol., 186, 407-421 (1990).

19) Okada T., Hayakawa R., Yoshino K., Komura S., Kondo K., Ohnishi N., Yagi K., J. Clin. Biochem. Nutr., 9, 171-178 (1990).

20) Scarpa K., Stevanato R., Viglino P., Rigo A., J. Biol. Chem., 258, 6695-6697 (1983).

21) Uchida K., Kawasaki S., Bioorg. Chem., 17, 330-343 (1989).

22) Peterkofsky B., Prather W., J. Cell. Physiol., 90, 61-70 (1976).

23) Jampel H. D., Arch. Ophthalmol., 108, 1323-1325 (1990).

24) Riley M. V., Schwartz C. A., Peters M. I., Curr. Eye Res., 5, $207-216$ (1986).

25) Murakami K., Muto N., Fukazawa K., Yamamoto I., Biochem. Pharmacol., 44, 2191-2197 (1992).

26) Pathak M. A., Stratton K., Arch. Biochem. Biophys., 123, 468-476 (1968).

27) McCall J. M., Braughler J. M., Hall E. D., Acta Anaesthesiol. Belg., 38, 373-379 (1987).

28) Kuppusamy P., Zweier J. L., J. Biol. Chem., 164, 9880-9884 (1989).

29) Abe Y., Okada S., Nakao R., Horii T., Inoue H., Taniguti S., Yamabe S., J. Chem. Soc., Perkin Trans., 2, 2221 -2232 (1992).

30) Doba T., Burton G. W., Ingold K. U., Biochim. Biophys. Acta, 835, 298-303 (1985).

31) Sato K., Niki E., Shimasaki H., Arch. Biochem. Biophys., 179, 402-405 (1990).

32) Shindo Y., Witt E., Han D., Espstein W., Packer L., J. Invest. Dermatol., 102, 122-124 (1994).

33) Yohn J. J., Norris D. A., Trasforza D. G., Buno I. J., Leff J. A., Hake S. S., Repine J. E., J. Invest. Dermatol., 97, 405-409(1991).

34) Martensson J., Meister A., Martensson J., Proc. Natl. Acad. Sci. U.S.A., 88, 4656-4660 (1991).

35) Rice-Evans C. A., Diplock A. T., Free Radical. Biol. Med., 15, 77-96 (1993).

36) Shindo Y., Witt E., Packer L., J. Invest. Dermatol., 100, 260-265 (1993). 